\title{
Greek Management and Culture
}

\section{Charalampos Giousmpasoglou}

Bahrain Polytechnic

\section{Abstract}

Since the late 1990s, an on-going debate has existed in Greece among academics and practitioners whether management is maintaining its national character or it is moving towards a model that potentially clashes with the country's traditional societal values. Greece, as a full member of the European Union since the early 1980s, has transformed its agricultural driven economy to a services one. This transition was made possible with the adoption and adaptation of western management practices, through the presence of multinational corporations in the country. This paper explores the Greek management context from various perspectives such as the national culture distinctive characteristics (i.e. dominant societal values) and the findings of research conducted on the Greek management context since the early 1980s. The overall conclusion is that Greek management is influenced by both the European/global business environment and the national/local distinctive characteristics and societal values. Based on the existing literature it was found that until the end of 2000s Greek and Western management co-existed in a delicate balance. What remains to be seen are the devastating results of the prolonged economic crisis that has affected not only Greece, but all Southern European countries. The balance is now disturbed and we are only at the begging of our understanding of this new reality, not only in management and the workplace but in also in our everyday lives.

Key Words: Management, National Culture, Societal Values, Greece

\section{Corresponding Author:}

Charalampos Giousmpasoglou, Bahrain Polytechnic, PO Box 33349, Isa Town, Bahrain

E-mail: c.giousmpasoglou@polytechnic.bh; babisyious@googlemail.com 


\section{Introduction}

It is arguable that the notion of national culture constitutes the most elusive and yet tantalising concept for both management theorists and practitioners. It can be argued however, that when research focuses on the Greek context it becomes extremely difficult to come to any conclusion about the role of culture in relation to managerial work because a limited number of studies and research has been conducted in this field. The following discussion is an effort to provide a general overview of the cultural context that Greek managers operate in. It is thus necessary, to highlight some important cultural-contextual dimensions of Greek management, which will provide a better understanding of the Greek context.

\section{The Greek dominant values}

People in organisations cannot be understood unless we examine the context they live and work. According to Sagiv and Schwartz (2007), the societal culture influences organisational and individual values in a direct or indirect manner.

Figure 1: Dominant values and characteristics in Greece

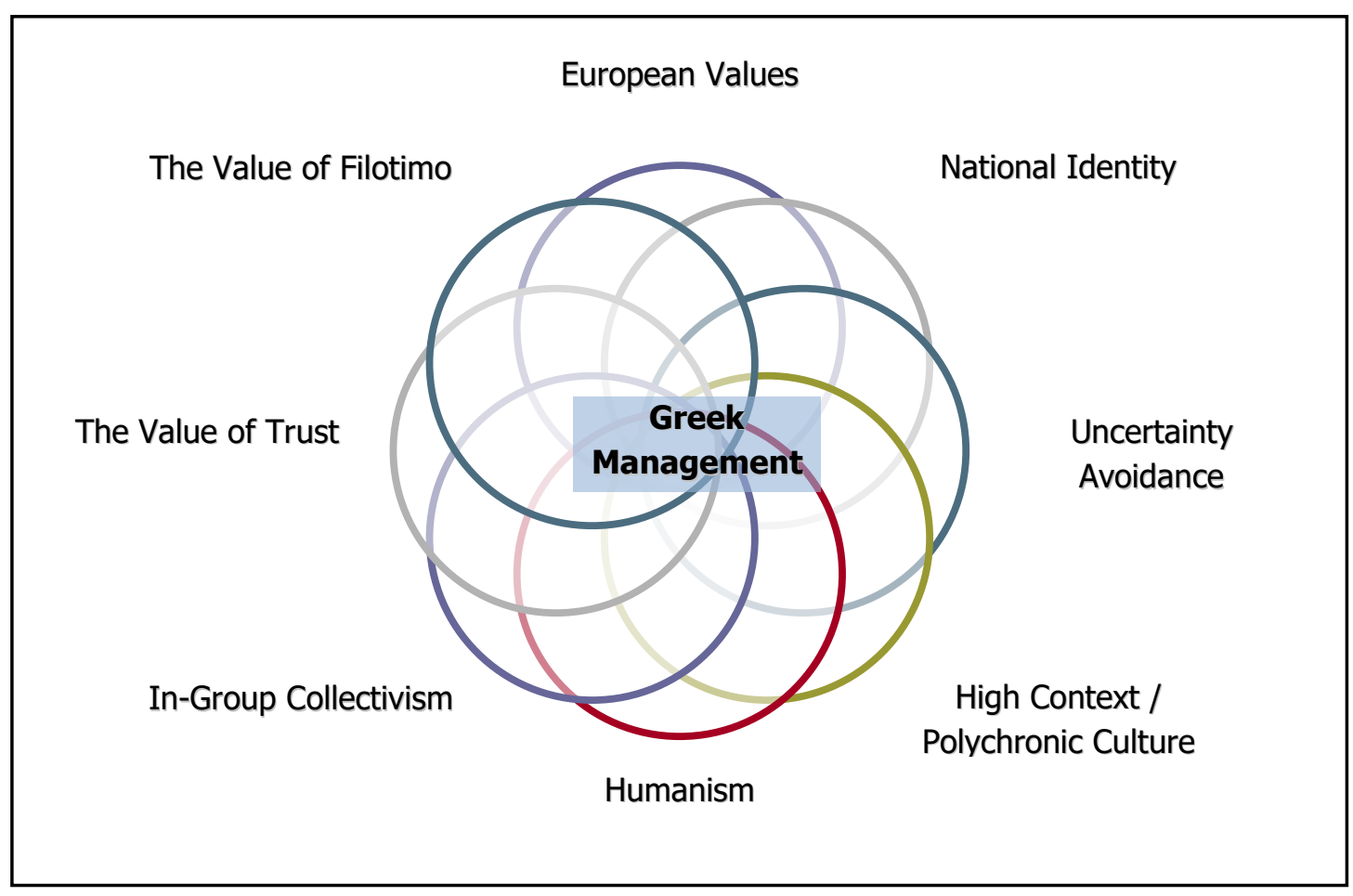


Thus, a good starting point for our discussion in Greek management is to explore the dominant cultural values and characteristics. Cultural values are broad goals that members of a society/group are encouraged to pursue; they serve to justify actions taken in pursuit of these goals (Schwartz, 1999). Cultural values also shape personal values through the process of socialisation. Thus it is common for members of each society to exhibit some value similarity (Sagiv \& Schwartz, 2007). Figure 1 emerges from the literature review that follows and provides an overview of the dominant Greek values and characteristics; each value/characteristic is discussed separately below.

\subsection{Uncertainty Avoidance}

More than three decades ago, Hofstede (1980) found that, of the 53 countries included in his sample, Greece is characterised by the highest 'uncertainty avoidance' index (UAl). This dimension refers to the extent to which its members seek orderliness, consistency, structure, formalised procedures and laws to cover situations in their daily lives. Greece was also found in the same study, to embrace a moderate to high masculine culture (MAS). On the basis of these two characteristics, he suggested that the need for security and status as a result of wealth is especially important to Greeks. In addition, Greece appears to have a greater collectivist orientation (IDV) among other European countries (Kalogeraki, 2009). It is no surprising that in leadership styles by which people would like to be managed, Hofstede $(1980,1991)$ showed that the consultative style is greatly preferred over other styles in Greece (e.g., 70\% of respondents preferred the consultative style, $18 \%$ the participative, $12 \%$ the persuasive, and $0 \%$ the autocratic). This survey reflected the will of people for change in a time that management was perceived as authoritative and an autocratic function in a rather conservative and depressed society. The relationship between collectivism and consultative leadership styles is discussed later in this paper (section 3). Lyberaki and Paraskevopoulos (2002) argue that these characteristics are partly attributable to the long tradition of authoritarian statism, but they also reflect the problematic transition from the military junta to democracy in the second half of the 1970s. It can be argued that since Hofstede's research in the late 1970s, Greek managers have significantly adapted their autocratic and paternalistic national management style, 
conditioned by their national culture, to the international corporate culture studied abroad (Makridakis et al., 1997). In addition, the societal values and the way that companies are structured and operate have made many steps towards convergence with the rest of the EU despite the significant cultural differences (Georgas, et al., 1997; Myloni et al., 2004; Triandis et al., 1986). Another indication of the above described change is the UAI results from the Globe project in the late 1990s. Quite surprisingly, Greece scored low in uncertainty avoidance which practically means that at the time of the survey there was a strong tolerance of ambiguity and uncertainty. As a result, people are used to less structure and order in their lives and are not as concerned about following rules and procedures. In low uncertainty avoidance countries people are not used to structured or organised communication. Meetings are not planned in advance, they have not set time and there is a tendency to have open-agenda or no agenda at all. This dimension is linked directly with the Greek high context polychronic culture (see 1.6 below).

\subsection{National Identity}

Bozatzis $(1999,2004)$ argues that a distinctive characteristic of the Greek culture is the strong national identity or pride. As a social phenomenon it involves feeling proud to be the national of a particular country, appreciating the nation's problems and participating in problem solving, believing the country is fulfilling its goals, taking personal pride and joy in achievements, introducing oneself openly as a national, and encouraging friends and close acquaintances to see one's country in a positive light (Karkatsoulis et al., 2005; Smith, 1996; Tajfel, 1979). National pride is linked to patriotism and nationalism, but being proud of one's country is not the same as being nationalist (Krause, 2012). Broome (1996, p.22) suggests that the Greek identity 'has never been a simple issue'; he further argues that Greeks have a very strong sense of themselves, a sense that is connected to language, religion, culture and historical continuity.

\subsection{The Value of Philotimo}

The working culture of Greeks is based on a sense of honour, dignity, loyalty and a sense of duty what is referred in the Modern Greek language as the value of 'philotimo'. There is no equivalent for this word in English; literally translated, 
it means love of honour and, as a concept it implies a self-imposed code of conduct based on trust and fairness (Broome, 1996). As Triandis (1972) indicates, a person who is considered philotimos behaves toward members of his or her in-group in a way that is 'polite, virtuous, reliable, proud, truthful, generous, self-sacrificing, tactful, respectful and grateful' (p. 308). Philotimo requires a person to sacrifice him - or herself to help family or friends and to avoid doing or saying things that reflect negatively on them. Appropriate behaviour should be seen and felt, not only by the in-group but by the out-group as well, thus increasing prestige for the former in the eyes of the latter. Philotimo often helps in overcoming difficulties and encouraging cooperation between workers or staff, which no rule or order could impose. It also means that, if treated 'properly', an employee will give more than what is normally expected in order to please his or her employers; in this case 'properly' means being respected, praised, and shown concern with regard to personal matters (Papalexandris, 2008).

The value of philotimo appears similar to the concept of face as has appeared in the Chinese and other Asian cultures. Face is a person's dignity, self-respect, status and prestige Ho (1976). To some extent the value of 'philotimo' appears some similarities to simpatia script characteristic of Hispanic people who want to have good relationships with others, i.e. want others to see them as 'simpatico' (Triandis et al., 1984).

\subsection{The Value of Trust}

Another distinctive characteristic found among the Greek managers is the value of Trust. Interpersonal trust is distinguished according to whether it is directed to relatives or friends, on one side, or to strangers, on the other (Putnam, 2000). Fukuyama's (1995) analysis of Trust suggests that interpersonal trust is basic for a wide variety of social relationships to emerge; he also argues that interpersonal trust is basic to a flourishing economy. Fukuyama also found that in family oriented societies like in Greece, there are strong families with weak bonds of trust among people unrelated to one another. These societies are dominated by family owned and family managed business - in the case of Greece more than $97 \%$ (ICAP, 2011). In this type of business there is a strong 
preference for authority that is centralised, hierarchical and formally or legally defined (Coviello \& McAuley, 1999; Mihail, 2004). Disputes between individuals of the same status are difficult to resolve without reference to a higher and centralised form of authority. In general, Fukuyama (1995) suggests a correlation between hierarchy and the absence of trust that characterises lowtrust societies. Hierarchies are necessary because not all people within a community can be relied upon to live by tacit ethical rules alone. They must ultimately be coerced by explicit rules and sanctions in the event that they do not conform / comply with these rules. Importance of the family is underpinned by the apparent weakness of voluntary citizens' welfare associations purported to function as intermediate protective layers between the family and the state. Therefore, the family has to absorb all vibrations inflicted by the state bureaucracy and/or by the working environment (Broome, 1996; Fukuyama, 1995). One should expect that the prevalence of a 'familial' social organisation would cause a high societal sensitivity to family values (Becker, 1995), also that the family business might constitute the social tissue that strengthens societal cohesion. In Greece instead, a hybrid of the 'Montegrano model' (Banfield, 1958) seems to unfold, by which families survive and prosper by striving against one another (Broome, 1996), as well as against the state (Stavroulakis, 2009). Although family ties have loosened in recent years, the family still constitutes the fundamental nucleus of Greek society (Halman, Sieben, \& van Zundert, 2011)

\subsection{The Value of Humanism}

The importance of family and the 'in-group' members, leave Greek managers with no other option than to adopt the humanist or people-oriented approach that is common in family business in southern Europe (Portugal, Spain, Italy and Greece) and Ireland. Humanism is defined by Webster's Dictionary as 'pertaining to the social life or collective relations of mankind; devoted to realising the fullness of human being; a philosophy that asserts the essential dignity and worth of man'. Humanism puts a strong emphasis on the family group and the community, which creates a sense of personal obligation and duty. The society overall is characterised by opportunism, change, flexibility and adaptability. Entrepreneurship and business are based on family, community, or 
socio-economic networks. The management style in this case is personalised and 'convivial. Humanism in Greece has strong links with the value of philotimo (see 1.3) and in-group collectivism (see 1.7).

\subsection{High Context Culture}

Greek managers are also influenced by the country's high context culture. Context here is defined in terms of how individuals and their society seek information and communicate (Hall \& Hall, 1990). People from high context cultures obtain information from personal information networks. Before such people make a decision, or arrange a deal they have become well informed about the facts associated with it. They have discussed the matter with friends, colleagues or even family members. They will have asked questions and listen to rumours or gossip. On the other hand, people from low context cultures seek information about decisions and deals from a research database whilst they would also listen to the views of colleagues or relatives (Morden, 1999). For most Greeks, matters can always be settled tomorrow; Hall and Hall (1990) call this a polychronic culture. Making and keeping appointments in Greece is not an easy task. Generally there is a more relaxed attitude toward the time of appointments, since everyone is aware of the difficulty involved in getting from one place to another, especially in Athens as well as other large cities. However, many managers are now accustomed to following the western practice and they expect punctuality regarding appointments and meetings (Broome, 1996).

The implications for Greek managers operating in a high context and polychronic environment are profound - especially when dealing with 'Westerners' from low context and polychronic cultures. American and European multinational companies were the first that experienced these difficulties back in the 1960s. The problem was - and to a large extent is - that western managers value most performance and business whilst Greeks value relationships and goodwill alongside with performance. In addition the mix of monochronic with polychronic cultures may result to unpredictable situations; it can either give rise to constant culture clash and disagreement or may yield synergies as features of each complements the other (Morden, 1995). Part of 
the problem was solved as many Greek and multinational companies' executives received Anglo-Saxon education and training where management is seen as a general and transferable skill. The creation of this new cohort of managers has been a small step towards convergence with the rest of the EU regarding managerial behaviour. It is however questionable if Greek managers will ever fully comply with the established western management values and practices (Myloni et al., 2004).

\subsection{In Group Collectivism}

In the early 1970s Triandis \& Vassiliou (1972) observed that Greeks behaved much more differently when they interfaced with an in-group (i.e. the family) than with an out-group (i.e. strangers). Within the 'in-group' there is warm acceptance of people with authority, and behaviour is cooperative and given to self-sacrifice (the value of philotimo). By contrast, there is a cold rejection of out-group authorities, and behaviour toward out-group people is suspicious, hostile, and extremely competitive (Georgas, 1993). This behaviour is described by the GLOBE project as in-group collectivism and is central to the Greek culture (Papalexandris, 2008).

In-group collectivism (also referred as family collectivism) reflects the extent to which a society's institutions favour autonomy versus collectivism. It also refers to the extent to which members of a society take pride in membership in small groups such as their family and circle of close friends, and the organisations in which they are employed. Papalexandris et al. (2002) indicate that one of the main characteristics of the Greek culture is strong family bonds, even though in big cities there might have been a recent change in this respect. The father is the centre of the family; he is responsible for all its members and the one who makes the final decision. There is a strict hierarchy and younger members are expected to show respect to the older. Power is concentrated in a few hands, which is usually accepted although it does not go unquestioned. Family members and close friends tend to have strong expectations from each other. Taking care of their needs and satisfying their expectations is critical to each individual. It is not unusual to forego due diligence, or equal employment opportunity, and to favour a close friend or family member in recruiting or in 
allocating rewards and promotions. Making regular references to one's family and especially one's father is quite acceptable and can go a long way in opening doors. All the above explain the existence of hierarchical clientelistic networks and the relatively high levels of corruption that shadowed the Greek society throughout its modern history (Lyberaki \& Paraskevopoulos, 2002).

\subsection{European Values}

The study of European values has drawn the attention of researchers since the early 1970s. The European Values Study (EVS) is the most comprehensive research project on human values in Europe. It's a large-scale, cross-national, and longitudinal survey research program on how Europeans think about family, work, religion, politics and society (http://www.europeanvaluesstudy.eu/). Greece has participated twice in this survey (1999 and 2008). When compared to the rest of Europe some interesting findings emerge regarding the Greek values. The comparisons revealed (Figure 2) that people in Greece attribute significantly more importance to power / achievement (POAC), conformity / tradition (COTR), universalism / benevolence (UNBE), hedonism / stimulation (HEST), and stimulation / self-direction (STSD) (Davidov et al., 2008).

Figure 2 Summary of Greece's results in EVS

Definitions:
POWER (PO): Social status and prestige, control or
dominance over people and resources
ACHIEVEMENT (AC): Personal success through
demonstrating competence according to social standards
HEDONISM (HE): Pleasure and sensuous gratification for
oneself
STIMULATION (ST): Excitement, novelty, and challenge in
life
SELF-DIRECTION (SD): Independent thought and action-
choosing, creating, exploring
UNIVERSALISM (UN): Understanding, appreciation,
tolerance and protection for the welfare of all people
and for nature
BENEVOLENCE (BE): Preservation and enhancement of
the welfare of people with whom one is in frequent
personal contact
TRADITION (TR): Respect, commitment and acceptance
of the customs and ideas that traditional culture or
religion provide the self
CONFORMITY (CO): Restraint of actions, inclinations, and
impulses likely to upset or harm others and violate social
expectations or norms
SECURITY (SEC): Safety, harmony and stability of society,
of relationships, and of self
SourCe: adapted from Davidov et al., 2008


In a similar study conducted in 2008 (Eurobarometer 69), it was found that Greeks demonstrate less tolerance and respect for other cultures. In addition, religion still plays a key role in society as a whole (Table 1). Both studies confirm the importance of family in Greek society and the lack of institutional (i.e. the government, the police, the education system) and interpersonal trust. The low levels of trust in Greece are also found in World Values Study (Morrone, Tontoranelli and Ranuzzi, 2009).

Table 1 Personal Values, Greece Vs EU

\begin{tabular}{|l|c|c|l|c|c|}
\hline \multicolumn{1}{|c|}{ Value } & GR \% & EU 27 \% & \multicolumn{1}{c|}{ Value } & GR \% & EU 27 \% \\
\hline Peace & 57 & 45 & Equality & 20 & 19 \\
\hline Human Rights & 43 & 42 & Tolerance & 1 & 16 \\
\hline Respect of Human Life & 44 & 41 & Solidarity & 13 & 13 \\
\hline Democracy & 30 & 27 & Self-fulfillment & 9 & 11 \\
\hline Individual Freedom & 19 & 21 & Religion & 18 & 7 \\
\hline The rule of Law & 24 & 21 & $\begin{array}{l}\text { Respect for other } \\
\text { cultures }\end{array}$ & 5 & 9 \\
\hline
\end{tabular}

Source: Standard Eurobarometer 69 (2008)

\section{Studies related to Greek management culture}

Early research concerning the management of Greek organisations has suggested that management is underdeveloped relative to other national EU partners (Greek Management Association, 1986). From the few empirical studies that refer to the Greek management culture, it is not easy to classify Greece as a member of any one of the clusters of countries suggested by Hofstede (1980, 1991) and his successors (i.e. Hampden-Turner \& Trompenaars, 1994). The literature provides however some interesting data relating to management culture in Greek context. In the post-second world war years during the 1950s and 1960s there was a high level of unemployment and a significant amount of immigration to industrialised countries like Germany and the United States. The level of education among employees, managers, and entrepreneurs was low. The civil war, which broke out in Greece just after World War Two, had only just been resolved, and for several years the political situation was unstable and lacking in the basic elements of democracy. 
The majority of empirical studies that were carried out in Greece during the 1970s and 1980s, sketch a period where the level of industrialisation, the growth rate, and the level of disposable income were very low (Bourantas \& Papadakis, 1996). As early as in the early 1970s, Cummings \& Schmidt (1972) examined the relative roles of cultural background and degree of industrialisation in the managerial beliefs of a sample of Greek managers. Findings were compared with the previous results reported by Haire et al. (1966) and Clark \& McCabe (1970). The Greeks were as inconsistent as those in these two previous studies in displaying little belief in their subordinates' capacities for leadership and initiative while advocating the practice of participative management. On two beliefs (capacity for leadership and initiative and belief in internal control) the Greeks tended to cluster with a Latin-European cluster, (Spain, Italy, Portugal, France) (www.worldvaluessurvey.org) thereby suggesting a cultural explanation. On the other hand, regarding beliefs in sharing information with subordinates and participative management the Greeks clustered with a developing countries cluster, thereby suggesting an industrialisation explanation. Exclusive focus on either explanation of managerial attitudes and beliefs does not seem warranted.

A study by Bourantas et al. (1987) addressed whether there have been significant changes since the early 1950s, in the needs of Greeks. Indeed, their empirical data suggest a process of evolution: the Greeks' physiological and security needs (Maslow, 1970) are relatively well satisfied, while new, higherorder needs now appear to be important. The 'ego needs' of self-esteem and status through wealth, which largely coincide with the national character of the Greek people, remain important, as would be logically expected. It can be suggested that Greek 'management' as something distinct has hardly existed until the early 1980s; all management practices and methods were largely adoption of multinational companies' practices. Kanelpoulos (1991) has documented a lack of wide diffusion of modern management methods and systems such as formal structures, planning and control systems, human resource management systems, incentive systems, and management information systems. Bourantas \& Papadakis (1996) argue that the salient characteristics of Greek management (in the 1980s and early 1990s) were 
firstly, concentration of power and control in the hands of top management, and secondly a lack of modern systems to support strategic decisions. A question raised here is whether management in Greece possesses any unique characteristics that distinguish it from other European management styles (e.g., the institutionalised participation of employees in Germany or Sweden and the informal network relationships among small and medium-sized enterprises in Italy). Bourantas \& Papadakis (ibid, p.17) argue that:

"...we are so far unable to single out one important dimension distinguishing Greek management from the management style of other European countries. We would rather characterize Greek management as a Western-type management style that has not yet reached a high level of modernization and adoption of scientific and analytical methods and techniques."

They also suggest that Greek management differs in the degree of modernisation and professionalism of management functions, management systems, and professional knowledge and skills. Thus, the differentiation of Greek management relative to that of other European countries is a matter of degree of development and does not constitute a different model. Although this view is correct and accepted by Greek academics and practitioners, it does not emphasise the role of culture in managerial work. This is normal because researchers at that time (early 1990s) in Greece focused their attention on the improvement of management practices and technological advancements.

Bourantas \& Papalexandris' (1992) empirical study of five hundred eighty eight Greek managers found that $74 \%$ of respondents perceived that their organisations reflected either the characteristics of an Eiffel Tower culture $(38 \%)$ or a Family culture $(36 \%)$, providing support for the classification of Greek organisations as either of these two organisational culture types. Consistent with Trompenaars' (1993) work, it is probable that the size of the Greek organisation differentiated between the implementation of a Family or Eiffel Tower organisational cultural form. The two dimensions of Trompenaars' model, hierarchy/equity and person/task, can be operationalised by considering the degree of centralisation and the degree of formalisation, respectively. Thus, Greek organisations are likely to adopt an Eiffel Tower culture, characterised by centralisation of decisions-making authority (hierarchy focus) and high reliance 
on formalisation (task focus). The hierarchy focus of the Eiffel Tower organisational culture seems congruent with Greek managers' high-power distance societal values (Joiner, 2001). Indeed, it is likely that encouraging Greek managers to increase their involvement in decision making may generate anxiety and lead to lower levels of performance. Such managers tend to prefer and respect a more non-consultative, decisive approach from their superior. Similarly, upper management inculcated with the values of a high-power distance culture, are likely to be reluctant to give up decision-making authority (perceived to be rightly bestowed upon them) to promote a relationship of greater equality in decision making (Veiga \& Yanouzas, 1991).

GLOBE (Global Leadership and Organisational Behaviour Effectiveness) is a research programme initiated in the late 1990s, focusing on the effects of societal culture on leadership, organisational practices and values in sixty-two nations, including Greece. National cultures are examined in terms of nine dimensions: performance orientation; future orientation; assertiveness; power distance; humane orientation; institutional collectivism; in-group collectivism; uncertainty avoidance; and gender egalitarianism. The participants in this survey were eighteen thousand middle managers in food processing (including luxury hotels), finance and telecommunications. The project used a multimethod approach by employing both qualitative and quantitative data. These data were collected from one hundred and fifty Country Co-Investigators (CCls) who were social scientists or management scholars. CCls ensured the accuracy of questionnaire translations and are responsible for the writing of each country's culture specific descriptions that derive from the interpretation of the qualitative data collected from the questionnaires. This process provided useful insights for each participative country's cultural perspectives in relation to management and leadership (Javidan \& House, 2001).

The GLOBE project concludes to some interesting findings, regarding the Greek management context (Table 2). Thus, when summarising the findings of the GLOBE project in Greece, the following about perceptions of societal culture can be suggested (Papalexandris, 2008). First, the participant managers are not satisfied with the performance orientation of their society and they wish that 
things should be planned more carefully. In addition, they are not satisfied with the high levels of assertiveness shown and they show a longing for more collective ways of life that was the rule in the past but is now threatened by rapid urbanization and modern ways of life. Moreover, Greek managers value family life and gender equality; they also long for a more caring society, which was the rule in the past. Greeks also resent power distance, which they perceive as high. Finally, they perceive their society as highly uncertain and would like this situation to improve.

Table 2: GLOBE results on Greek societal culture

\begin{tabular}{|c|c|c|c|c|c|c|c|}
\hline \multirow[b]{2}{*}{ Culture Dimensions } & \multicolumn{3}{|c|}{ Society "As Is" } & \multicolumn{3}{|c|}{ Society "Should Be" } & \multirow{2}{*}{$\begin{array}{l}\text { Differenced } \\
\text { "Should be" } \\
\text { - "As Is" d }\end{array}$} \\
\hline & Mean $^{a}$ & Band $^{b}$ & $\operatorname{Rank}^{c}$ & Mean & Band & Rank & \\
\hline Performance Orientation & 3.20 & $\mathrm{C}$ & 61 & 5.81 & $\mathrm{C}$ & 40 & 2.61 \\
\hline Future Orientation & 3.40 & $\mathrm{C}$ & 51 & 5.19 & $\mathrm{~B}$ & 48 & 1.79 \\
\hline Assertiveness & 4.58 & A & 9 & 2.96 & $\mathrm{C}$ & 57 & -1.62 \\
\hline Institutional Collectivism I & 3.25 & $\mathrm{D}$ & 61 & 5.40 & A & 5 & 2.15 \\
\hline In-Group Collectivism II & 5.27 & B & 35 & 5.46 & $\mathrm{~B}$ & 41 & 0.19 \\
\hline Gender Egalitarianism & 3.48 & A & 27 & 4.89 & A & 15 & 1.41 \\
\hline Humane Orientation & 3.34 & $\mathrm{D}$ & 59 & 5.23 & B & 48 & 1.89 \\
\hline Power Distance & 5.40 & A & 21 & 2.39 & $\mathrm{D}$ & 52 & -3.01 \\
\hline Uncertainty Avoidance & 3.39 & $\mathrm{D}$ & 57 & 5.09 & A & 17 & 1.70 \\
\hline $\begin{array}{l}\text { a. Country mean score on } \\
\text { b. Bands A>B }>C>D \text { are d } \\
\text { "As Is" and "Should } \\
\text { standard deviations are } \\
\text { procedure, cf. Hanges, I } \\
\text { c. The rank order for Gree } \\
\text { d. Absolute difference bet }\end{array}$ & $\begin{array}{l}\text {-point Lik } \\
\text { rmined by } \\
\text { scales } \mathrm{r} \\
\text { sed to cal } \\
\text { kson, and } \\
\text { relative to }\end{array}$ & $\begin{array}{l}\text { t-type sca } \\
\text { alculating } \\
\text { pectively } \\
\text { late low, } \\
\text { ipe, } 2004 \text { ) } \\
\text { he } 61 \text { cour }\end{array}$ & $\begin{array}{l}\text { he grand } 1 \\
\text { or the GI } \\
\text { hedium, a } \\
\text { ies. }\end{array}$ & $\begin{array}{l}\text { an and st } \\
\text { 3E sam } \\
\text { high ba }\end{array}$ & $\begin{array}{l}\text { dard de } \\
\text { of cou } \\
\text { s of col }\end{array}$ & $\begin{array}{l} \\
\text { tions a } \\
\text { tries. Tl } \\
\text { tries (C }\end{array}$ & $\begin{array}{l}\text { Oss all society } \\
\text { se means and } \\
\text { OBE standard }\end{array}$ \\
\hline
\end{tabular}

Source: Papalexandris (2008), p.780

\section{Discussion}

So far, the discussion of the dominant societal values and cultural influences indicates that in Greece exists a complex and multi-dimensional socio-cultural context. Managers operating in this context have a challenging task: to master all the societal values and cultural influences discussed in the previous 2 sections above. Figure 3 provides a synthesis of data from 4 studies (GLOBE, EVS, GVS, Eurobarometer 69) and demonstrates the complexity of the above 
described environment. The different scores reported for each study were converted to Likert scale (1: very low -5 very high). There was no intention to provide statistical data in Figure 3 but to highlight the significance of each value and cultural dimension in Greek society. Although the scope of this paper is not to discuss each dimension separately, the generic context is provided in part one where the existing studies and cultural values are explained.

Figure 3 Societal values and cultural influences in Greece

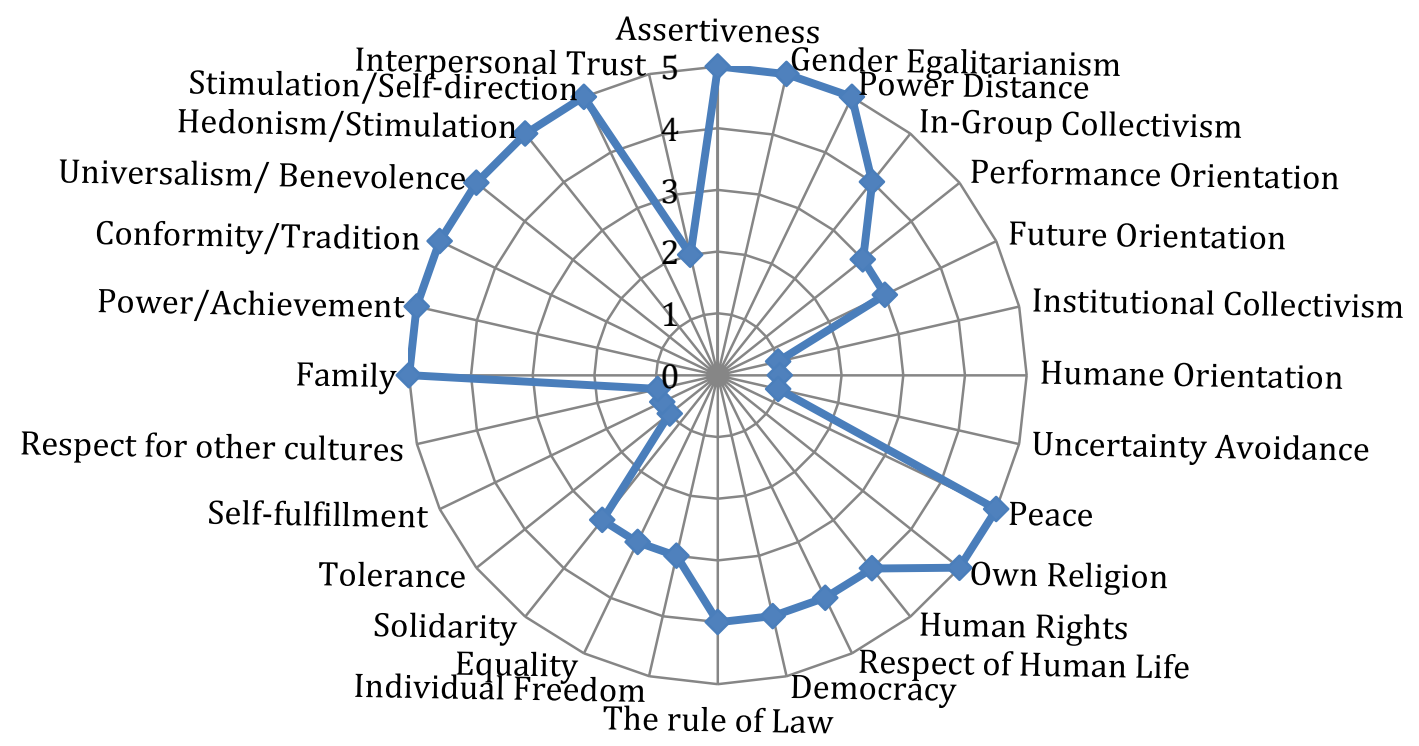

Source: data from GLOBE, EVS, GVS, Eurobarometer 69

The above figure sketches very well the challenges that the national work context poses for managers operating in Greece. Broome, (1996, p.79) argues that 'in Greece you must manage persons, not personnel. Thus, based on the family collectivism culture discussed above, the successful Greek manager is expected to take care of employee needs as they arise, showing an interest in their family problems, because for most Greeks, family and the 'in-groups' are more important than work (Lyberaki \& Paraskevopoulos, 2002; Lyrintzis, 2011). The personal relationship with employees and the ability of the manager to develop and maintain personal connections with both subordinates and colleagues is often what distinguishes a leader from a manager, especially at 
the middle levels of hierarchy (Broome, 1996). In fact, there is no corresponding translation for manager in Greek language. For higher levels, the word most often used is 'diefthintis', meaning director (Papalexandris, 2008). Indeed, many managers still carry out their jobs in a more directive and controlling approach than is commonly found in Western companies. Research in the mid-1960s showed that autocratic management was a consequence of the family structure and the lack of separation between ownership and management (Alexander, 1968). Today, even in family-owned companies, which could be characterised as patriarchal, very rarely does the directive style mean harsh treatment to employees (Papalexandris, 2008). As relationship bonds run deep in Greek culture, the manager expects loyalty. In return for this loyalty the boss will look after the interests of subordinates (Broom, 1996). The manager-subordinate relationship is viewed as reciprocal. This is what Sagiv \& Schwartz (2007) describe as embedded cultures, where employees are viewed as entities embedded in the collectivity. They argue that organisations located in societies high on embeddedness (i.e. Greece) are more likely to function as extended families, taking responsibility for their members in all domains of life; in return it is expected from their members to identify with and work dutifully towards shared goals. In-group solidarity is protected with restraining actions against inclinations towards the possible disruption of the status quo (Yolles and Fink, 2013); the role of the manager here is to warn his/hers subordinates about the consequences which include social exclusion or even suspension from the group.

In addition, Broome (1996) suggests that because the thinking process of Greek managers is 'nonlinear', there does not seem to be a need, such as in most western countries, to complete tasks in a serial manner. Thus, it is not uncommon in Greece to find several people in a manager's office at the same time, each with a different concern, or the manager might be on two phones, concurrently working on various tasks at different stages of completion, all the while receiving and passing messages to the secretary or giving directives to other employees. Thus, in relation with time, Greek managers tend to deal with several items simultaneously and to cope well with constant interruptions, often in an unplanned or opportunistic sequence (Broome, 1996). They may not be 
interested in time schedules or concepts of punctuality. They consider that the reality of events and opportunities is more important than adherence to what they perceive to be artificial constructs of planning, schedules and appointments. Time is neither seen as a resource nor as an opportunity cost that equates to money - behaviour synonymous to western management practices. This behaviour can be explained based on the high-context polychronic culture (Hall \& Hall, 1990) discussed above in 1.6.

Moreover, Greeks are both very individualistic and independent (Papalexandris, 2008; Triandis \& Vassiliou 1972); as a result they do not like to be told what to do without proper explanations. They also dislike orders and are not at all intimidated by status; they face difficulties in cooperating and are very quick to question authority and mistrust superiors. Therefore, only the person/manager who can win approval, encourage teamwork, and be recognised as superior due to his or her qualities, skills, fairness, and integrity, can be characterised as a leader. This behaviour is linked with the low levels of interpersonal trust (EVS, 2008) and the in-group collectivism discussed above. It is also linked with what Sagiv \& Schwartz (2007) label as mastery: cultures that embrace mastery encourage active self-assertion in order to master, direct and change the natural and social environment to attain group or personal goals.

The exploration of the Greek management context in this paper so far, was focused on the effect of societal values and culture on the national management character. From a management perspective, there are strong indications that both convergence and divergence with the rest of the EU occurs simultaneously. Thus, pressures for convergence are emerging from the country's obligations as a member of the EU and several other organisations, which require planning ahead, and efficient management of the various projects. While this affects mostly the public sector, globalisation puts pressures for uniform management practices and policies on private sector organisations (Anastasakis and Singh, 2012). Thus, a slow but steady movement towards harmonisation of management practices at least with the rest of the E.U. members is observed. On the other hand, a certain level of differentiation from the average E.U. social and working conditions within the Greek context 
provides the basis for the argument that it is not only the right mix of competencies or the adoption of best practices that makes a manager successful but also the understanding of the work context itself. Thus, practices such as the use of recommendations and references in recruiting employees for both Greek firms and foreign subsidiaries - are still common even in larger Greek companies based on evidence from the GLOBE project (Myloni et al., 2004).

Greek managers were brought up in a differentiated socio-cultural context (comparing to the rest of Europe), which affects directly and indirectly the nature of their organisational tasks (Sagiv \& Schwartz, 2007). Chalari (2012, p.36) argues that 'Modern Greek history distinguishes that country from Northern European nations, since during the periods when Europe enjoyed stability and progress Greeks had to resolve their own domestic political and social discontinuities'. Thus it is imperative that managers and people of foreign origin should remember that Greece is a country with a complex past history where ancient myths blend with modern reality (Papalexandris, 2008). This has led to a vast and diversified pool of values, attitudes, and behavioural patterns, from which individuals draw to form their own character and personality. As a concluding point here we can argue that despite the country's convergence in management practices with the rest of the western world, a distinctive national character signposts the development (or underdevelopment) of management in Greece.

\section{An alternative conclusion: where do we go from here?}

Greece (and to some extent its Southern European counterparts) is going through a radical social transformation. All the major European studies mentioned above regarding management in relation to societal values and cultural influences were unable to predict the devastating effects of the economic crisis in countries like Greece, Cyprus, Ireland, Spain and Portugal. Organisations in general and managers in particular, cannot remain unaffected from these changes since they must gain and maintain a minimal level of approval from society in order to function effectively (Sagiv \& Schwartz, 2007). 
Greek society is currently undergoing a radical social change; all the traditional values that formed post-war Greece are now in dispute (Transparency International, 2012). The country has been 'reformed' with unnecessary cruelty since for many years it has been the 'black sheep' of the European statistics (PEW Research, 2012). On the other hand the latest Eurostat (2011) data released, reveal that the Greeks (especially the managers) are the most hardworking among Europeans. So, what is missing with the interpretation of the current situation? Apparently there was a structural problem originating from the creation of a disproportional public sector that served clientelistic and populist practices for the past three decades (Chalari, 2012). In addition, the country missed a golden opportunity in the 2000s to introduce reforms through its entrance in the common currency and the host of the 2004 Olympic Games. Lyrintzis (2011) argues that significant cultural changes had taken place during this decade which has led to complacency and indifference. There were also discrepancies in the way that the Greek problem was dealt by the European technocrats: the decisions made for the future of the country were based on false statistics. How can you come to safe conclusions in country that grey economy reached 30\% (Transparency International, 2012)? Apparently it was very difficult for the rest of Europe to realise how the real economy works and what would be the impact of the extreme austerity measures imposed upon Greek society.

A new social reality is emerging in the Greek society and the national management character cannot be unaffected. Greeks thus are currently faced with high rates of unemployment (especially among young people), increasing suicide rates (http://eurohealthnet.eu/organisation/rate-suicide-increased-40greece), continues lack of trust (interpersonal and institutional), unprecedented austerity measures and overall political and social instability (Chalari, 2012). Another disturbing phenomenon is the increasing brain drain (Greeley, 2012), the migration of the young highly educated population in developed countries who can capitalize their talent. Based on empirical research Labrianidis and Vogiatzis (2012) argue that it is not reasonable to believe that these people will return to Greece, especially given the prolonged economic and social crises. 
So where do we go from here? There are currently signs of reflexivity in the Greek society especially from the younger generations. Reflexivity is defined by Archer (2007) as the ability of individuals to consider themselves in relation to themselves and the social environment. According to May (2011) people respond to social change in a 'fragmentary fashion' and she clarifies that the way people are affected relates to the gradual alteration of their ways of thinking as well as to their habits and routines. Thus, in order to examine how the Greek society (and management) is changing, we need to explore whether and how Greek managers have altered their way of thinking, their practices, values, routines and in more general terms the way they perceive social reality within and outside their work environment. Furthermore, we should question why this kind of research is necessary and for whom? The second half of the $20^{\text {th }}$ century is dominated by research conducted in North America by researchers who worked and lived mainly in the USA (Thomas, 2008). Our understanding of what management is, what and why managers do what they do, and what makes a good manager are based on assumptions and data derived from this context. Despite the emergence of International and Cross Cultural Management as sub-disciplines in higher education curricula, management remains largely an American construct. Based on the above discussion and the existing literature (i.e. Broom, 1996; Papalexandris, 2008; Sagiv \& Schawrtz, 2007) it is more than evident that management is shaped and influenced by context, especially by societal values and cultural characteristics. It is also influenced by social changes since people alter and adapt their fundamental values and beliefs to the new reality. Thus, there is a necessity to understand the impact of the current economic crisis in local, European and global context; this necessity emerges from the need to create better workplaces through the development of capable managers who can survive in an ever-changing environment. What we currently teach business students and what we practice in organisations belongs to the past. 


\section{References}

Alexander, A. (1968) Greek industrialists (Research monograph series), Athens: Centre of Planning and Economic Research (in Greek)

Archer, M.S. (2007) Making our way through the world, Cambridge: Cambridge University Press Banfield, E.C. (1958) The Moral Basis of a Backward Society, New York: Free Press

Becker, G.S. (1995) Housework: The Missing Piece of the Economic Pie, Newsweek, October 16, p.30

Billig, M. (2001) Discursive, Rhetorical and Ideological Messages, in Wetherell, M., Taylor, S., Yates, S.J. (Eds) Discourse Theory and Practice: A Reader, London: Sage, pp.210-221

Bourantas, D. and Papalexandris, N. (1992) Variables affecting organizational commitment: private- versus publicly-owned organizations in Greece, Journal of Managerial Psychology, 7(1), pp. 3-10

Bourantas, D., Anagnostelis, J., Mantes, Y. and Kefalas, G. (1987) The influence of the sociocultural environment on Greek management, Unpublished report, Athens, (ГЕГЕT) General Secretariat for Research \& Development (in Greek)

Bourantas, D., and Papadakis, V. (1996) Greek Management: Diagnosis and prognosis, International Studies of Management and Organization, 26(3), pp.13-25

Bozatzis, N. (1999) Greek National Identity in Talk: The Rhetorical Articulation of an Ideological Dilemma, Unpublished PhD thesis, Lancaster University, U.K.

Bozatzis, N. (2004) Seismic Affection: The Cultural Politics of Identity Construction in Greek Press Coverage of Earthquakes in Turkey, in Gulerce, A., Hofmeister, A., Steuble, I., Saunders, G. and Kaye, J. (Eds) Contemporary Theorizing in Psychology: Global Perspectives, Ontario: Captus, pp. 355-64

Broome, B. (1996) Exploring the Greek Mosaic: A Guide to Intercultural Communication in Greece, Yarmouth: Intercultural Press, Inc.

Chalari, A. (2012) The causal powers of social change: the case of modern Greek society, The Hellenic Observatory, GreeSE Paper No.64, London:LSE

Clark, A.W. and McCabe, S. (1970) Leadership beliefs of Australian managers, Journal of Applied Psychology, 54, pp.1-6

Coviello, N.E. and Mc Auley, A. (1999) Internationalization and the Smaller Firm: A Review of Contemporary Empirical Research, Management International Review, 39(3), pp.223-256

Cummings, L.L. and Schmidt, S.M., (1972) Managerial Attitudes of Greeks: The Roles of Culture and Industrialization, Administrative Science Quarterly, June, pp.265-272

Davidov, E., Schmidt, P. and Schwartz, S. H. (2008) Bringing values back in the adequacy of the European Social Survey to measure values in 20 countries, Public opinion quarterly, $72(3)$, pp.420-445

Earley, P.C. (1993) East meats West meets Mideast: further explorations of collectivistic and individualistic work groups, Academy of Management Journal, 36(2), pp.319-348

Eurobarometer, S. (69). 1. Values of Europeans. Carried out by TNS Opinion \& Social between 25 March and 4 May 2008 in 31 countries or territories and published in November 2008

Eurostat - Labour Force Survey (2011), available at http://appsso.eurostat.ec.europa.eu/nui/ show.do?dataset= Ifsa_ewhuis\&lang=en (accessed 16/5/2013)

Fukuyama, F. (1995) Trust: the social virtues and the creation of prosperity, London: Hamish Hamilton

Georgas, J. (1993) Management in Greece, in D.J. Hickson (ed.) Management in Western Europe: Society, Culture and Organisation in Twelve Nations, Berlin: Walter de Gruyter, pp. 109-124 
Georgas, J., Christakopoulou, S., Poortinga, Y., Angleitner, A., Goodwin, R. and Charalambous, N. (1997) The relationship of family bonds to family structure and function across cultures, Journal of Cross-Cultural Psychology, 28, pp.303-320

Greek Management Association (1986) The management practice in Greek enterprises, Athens: Greek Management Association (EEDE) (in Greek)

Greeley, B. (2012) Greece's Brain Drain has begun, Bloomberg Businessweek, available at http://www.businessweek.com/articles/2012-05-24/greeces-brain-drain-has-begun (accessed 16/5/2013)

Haire, M., Ghiselli, E., and Porter, L. (1966) Managerial thinking: An international study, New York: Wiley

Hall, E.T. and Hall M.R. (1990) Understanding Cultural Differences, Maine: Intercultural Press

Halman,L., Sieben, I. and van Zundert, M. (2011) Atlas of European Values: Trends and Traditions at the turn of the Century, Leiden, the Netherlands: Brill

Hampden-Turner, C. and Trompenaars, F. (1994) The Seven Cultures of Capitalism, London: Piatkus

Herzfeld, M. (1986) Ours Once More: Folklore, Ideology and the Making of Modern Greece, New York: Pella

Ho, D.Y.F. (1976) On the concept of Face, American Journal of Sociology, 81, pp.867-884

Hofstede, G. (1980) Cultures' consequences: international differences in work-related values, Beverly Hills: SAGE

Hofstede, G. (1991) Cultures and organizations: software of the mind, London: McGraw Hill

ICAP (2011) Greece in figures - Annual Report, Athens: ICAP - Greece

Javidan M.J. and House R.J. (2001) Cultural Acumen for the Global Manager: Lessons from Globe Project, Organizational Dynamics, 29(4), pp.289-305

Joiner, T.A. (2001) The influence of national culture and organizational culture alignment on job stress and performance: evidence from Greece, Journal of Managerial Psychology, 16(3), pp.229-242

Kanellopoulos, Ch. (1990) Personnel management and personnel managers in Greece, Athens, Greek Productivity Centre (in Greek)

Karkatsoulis, P., Michalopoulos, N. and Moustakatou V. (2005) The national identity as a motivational factor for better performance in the public sector: The case of the volunteers of the Athens 2004 Olympic Games, International Journal of Productivity and Performance Management, 54(7), pp.579-594

Kessapidou, S. and Varsakelis, N. (2002) The impact of national culture of international business performance: the case of foreign firms in Greece, European Business Review, 14(4), pp.268-275

KRAUSE, U. (2012) The Atlas of European Values Project: Mapping the Values of Europeans for Educational Purposes, European Journal of Geography, 3(2), pp.54-71

Labrianidis, L. and Vogiatzis, N. (2012) Highly Skilled Migration: What Differentiates the 'Brains' Who Are Drained from Those Who Return in the Case of Greece? Population, Space and Place

Lambropoulou E. (2007) The public discourse on corruption in Greece, Internet Journal of Criminology (accessed from: www.internetjournalofcriminology.com, on 10/1/2008)

Lessem, R. and Neubauer F. (1994) European management systems: towards unity out of cultural diversity, London: McGraw-Hill

Lewis, R.D. (1992) Finland: Cultural Lone Wolf - Consequences in International Business, Helsinki: Richard Lewis Communications

Lyberaki, A. and Paraskevopoulos, C. J. (2002) Social capital measurement in Greece, paper presented in International Conference on Social Capital Measurement, available at www.oecd.org/ dataoecd/22/15/2381649.pdf. (accessed 14/5/2013) 
Lyrintzis, C. (2011) Greek politics in the era of economic crisis: reassessing causes and effects, The Hellenic Observatory, GReeSE Paper No.45, London: LSE

Makridakis, S., Kaloghirou, Y., Papagiannakis, L. and Trivellas, P. (1997) The Dualism of Greek Firms and Management: Present state and future implications, European Management Journal, 15(4), pp. 381-402

Maslow, A.H. (1970) Motivation and Personality, New York: Harper \& Row

May, V. (2011) Self, belonging and Social Change, Sociology, 45(3), pp.363-378

Mihail, D. (2004) Labour flexibility in Greek SMEs, Personnel Review, 33(5), pp.549-560

Morden, A.R. (1995) National Culture and the Culture of the Organisation, Cross Cultural Management, Vol.2, No.2, pp.3-12

Morden, T. (1999) Models of National Culture: a Management Review, Cross Cultural Management, 6(1), pp.19-44

Morrone, A., N. Tontoranelli and G. Ranuzzi (2009) How Good is Trust?: Measuring Trust and its Role for the Progress of Societies, OECD Statistics Working Papers, 2009/03, OECD Publishing.

Myloni, B., Harzing, A.W. and Mirza, H. (2004) Human Resource Management in Greece: Have the colours of Culture faded away? International Journal of Cross Cultural Management, 4(1), pp.59-76

Papalexandris, N. (2008) Greece: From Ancient Myths to Modern Realities, in Chhokar, J., Broadbeck, F. and House, R. (Eds) Culture and Leadership Across the World: The GLOBE Book of In-Depth Studies of 25 Societies, London: Lawrence Erlbaum Associates, pp.767-802

Papalexandris, N. and Chalikias, J. (2002) Changes in training, performance management and communication issues among Greek firms in the 1990s: intercountry and intracountry comparisons, Journal of European Industrial Training, 26(7), pp. 342-352

Papalexandris, N., Chalikias, J. and Panayotopoulou, L. (2002) Societal Culture and Human Resource Management: Exploring the mutual interaction in Greece, paper presented at the $2^{\text {nd }}$ International Conference Human Resource Management in Europe: Trends and Challenges, Athens, Greece, 17-19 October 2002

Pew Research Center. Global Attitudes Project (2012) European Unity at the Rocks. Germany and Greece at Polar Opposites, Washington, D.C. May 29

Putnam R. D., (2000) Bowling Alone - The Collapse and Revival of American Community, New York: Simon \& Schuster

Sagiv, L. and Schwartz, S. H. (2007) Cultural values in organisations: insights for Europe, European Journal of International Management, 1(3), pp.176-190

Schwartz, S.H. (1999) Cultural value differences: some implications for work, Applied Psychology: An International Review, 48, pp.23-47

Smith, A.D. (1996) The Resurgence of Nationalism? Myth and Memory in the Renewal of Nations, The British Journal of Sociology, 47(4), pp. 575-598

Stavroulakis, D. (2009) HRM practices in view of internationalization. Evidence from business in Greece, MIBES Transactions, 3(1), pp.147-156

Tajfel, H. (1979) Individuals and groups in social psychology, British Journal of Social and Clinical Psychology, 18, pp.183-190

Thomas, D.C. (2008) Cross-Cultural Management: Essential Concepts, $2^{\text {nd }}$ Edition, London: Sage

Transparency International/TI (2012) National Integrity System Greece, available from http://www.transparency.org/whatwedo/pub/nis_greece_2012 (last accessed 14/5/2013)

Triandis, H.C. (1972) The analysis of subjective culture, New York: Wiley

Triandis, H.C. and Vassiliou, V.A. (1972) Interpersonal influence and employee and employee selection in two cultures, Journal of Applied Psychology, 56, pp.140-145 
Triandis, H.C. et al. (1986) The measurement of the etic aspects of individualism and Collectivism across the cultures, Australian Journal of Psychology, 38, pp.257-67

Triandis, H.C., Vassiliou, V. \& Nassiakou, M. (1968) Three cross-cultural studies of subjective culture, Journal of Personality and Social Psychology Monograph Supplement, 8(4), pp.1-42

Trompenaars, F. (1993) Riding the waves of culture, London: Nicholas Brealy

Veiga, J.F. and Yanouzas, J.N. (1991) Differences between American and Greek Managers in Giving Up Control, Organization Studies, 12(1), pp. 95-108

Yolles, M. and Fink, G. (2013) An Introduction to Mindset Agency Theory, Working paper of the Organisational Coherence and Trajectory (OCT) Project. Available at SSRN: http://ssrn.com/abstract=2272169 